\title{
Identifikasi Sebaran dan Karakteristik Ruang Terbuka Hijau Publik di Kota Pekanbaru
}

\author{
Syifa Nashella Rahmah Astaman, Hertiari Idajati, dan Fendy Firmansyah \\ Departemen Perencanaan Wilayah dan Kota, Fakultas Arsitektur, Desain, dan Perencanaan \\ Institut Teknologi Sepuluh Nopember \\ e-mail: hertiari.idajati@urplan.its.ac.id
}

\begin{abstract}
Abstrak-Ruang terbuka hijau di Kota Pekanbaru belum memenuhi ketentuan penyediaan $30 \%$, terutama ruang terbuka hijau publik. Penyediaan ruang terbuka hijau tersebut juga belum menyeluruh dan tidak merata. Sehingga, ruang terbuka hijau publik di Kota Pekanbaru, khususnya ruang terbuka hijau publik, belum memadai dilihat dari segi kuantitas dan kualitas. Padahal untuk dapat menjalankan fungsinya, suatu ruang terbuka hijau harus memenuhi ambang batasnya. Apabila ambang batas terpenuhi, maka efek pendinginan akan sesuai dengan target. Sehingga, harus dilakukan identifikasi sebaran dan karakteristik ruang terbuka hijau publik untuk mengidentifikasi masing-masing potensi dan masalahnya. Metode penelitian ini adalah dengan deskriptif. Hasil yang didapatkan adalah teridentifikasinya 48 ruang terbuka hijau publik yang terdiri dari taman, tempat pemakaman umum, lapangan, jalur hijau, dan hutan kota.
\end{abstract}

Kata Kunci-ruang terbuka hijau publik, karakteristik, persebaran, vegetasi

\section{PENDAHULUAN}

$\mathrm{R}$ UANG terbuka hijau merupakan salah satu faktor penting dalam sebuah sistem perkotaan. Berdasarkan UndangUndang No. 26 Tahun 2007 tentang Penataan Ruang, ruang terbuka hijau (RTH) adalah area memanjang/jalur dan/atau mengelompok, yang penggunaannya lebih bersifat terbuka, tempat tumbuh tanamanm baik yang tumbuh secara alamiah maupun yang sengaja ditanam. Berdasarkan ketentuan itu pula, setiap kota wajib menyediakan ruang terbuka hijau paling sedikit $30 \%$, dengan proporsi ruang terbuka hijau publik paling sedikit $20 \%$ dan ruang terbuka hijau privat $10 \%$.

Ruang terbuka hijau memiliki banyak fungsi, terutama terhadap lingkungan. Menurut Direktorat Penataan Bangunan dan Lingkungan, fungsi RTH diantaranya adalah mereduksi polutan, memproduksi oksigen, memperbaiki kualitas iklim lokal, mengontrol radiasi matahari, meningkatkan nilai arsitektural dan estetika, meningkatkan potensi turisme dan ekonomi, serta sebagai tempat interaksi sosial. Ruang terbuka hijau juga bergungsi untuk pengatur iklim mikro dan menyerap panas [1].

Meskipun sudah diatur oleh undang-undang dan memiliki manfaat yang banyak, tidak semua kota sudah menyediakan ruang terbuka hijau yang memadai, salah satunya adalah Kota Pekanbaru. Tahun 2013, di Kota Pekanbaru ruang terbuka hijaunya adalah sebesar $8.113,49$ dari luas total kota, yaitu $63.226 \mathrm{Ha}(12,83 \%)$, yang terdiri dari ruang terbuka hijau publik sebesar $1.790,89 \mathrm{Ha}(2,83 \%)$ [2]. Terlihat bahwa ruang terbuka hijau privat sudah memenuhi ketentuan, sedangkan ruang terbuka hijau publiknya belum memenuhi.

Penyediaan ruang terbuka hijau di Kota Pekanbaru juga belum menyeluruh dan tidak merata. Ruang terbuka hijau dengan kondisi yang baik dan memadai hanya terletak di pusat kota, sedangkan wilayah pinggiran belum memiliki sarana ruang terbuka hijau yang maksimal. Ruang terbuka hijau yang terletak di wilayah pinggiran umumya adalah hutan kota yang belum ditata dengan baik [3].

Sehingga, dapat disimpulkan bahwa ruang terbuka hijau di Kota Pekanbaru, khususnya ruang terbuka hijau publik, belum memadai dilihat dari segi kuantitas dan kualitas. Padahal, untuk dapat menjalankan fungsi ekologisnya secara maksimal, suatu ruang terbuka hijau harus memenuhi ambang batasnya yang berkaitan dengan kuantitas dan kualitasnya. Apabila ambang batasnya terpenuhi, maka efek pendinginan akan bekerja [4].

Maka, disusunlah penelitian ini yang bertujuan untuk mengidentifikasi sebaran dan karakteristik ruang terbuka hijau publik di Kota Pekanbaru. Sehingga, dapat diidentifikasi potensi dan masalah masing-masing ruang terbuka hijau publik dan ditentukan penanganannya.

\section{METODOLOGI PENELITIAN}

\section{A. Jenis dan Pendekatan Penelitian}

Pendekatan yang digunakan pada penelitian ini adalah pendekatan rasionalistik. Jenis penelitian ini adalah penelitian kuantitatif.

\section{B. Variabel Penelitian}

Berdasarkan kajian teori yang telah dilakukan, didapatkan beberapa variabel yang mendukung dalam penelitian ini. Variabel yang digunakan merupakan hasil dari sintesa pustaka pada bab tinjauan pustaka. Dalam penelitian ini, variabel yang digunakan untuk mengidentifikasi karakteristik ruang terbuka hijau publik, yaitu, luas, bentuk, proporsi, vegetasi, pola lansekap, sumber kelembababan, perawatan, dan tingkat peran masyarakat.

\section{Metode Pengumpulan Data}

Data-data yang dibutuhkan dalam penelitian ini diperoleh dengan cara survei lapangan, yaitu langsung dari sumbernya. Kemudian, data tersebut dilengkapi dengan data yang didapatkan dari instansi terkait, yaitu, Dinas Pekerjaan Umum dan Penataan Ruang Kota Pekanbaru. Teknik pengumpulan 
data yang digunakan adalah dengan observasi berdasarkan lembar observasi yang sudah disesuaikan dengan variabel penelitian.

\section{Tahapan Penelitian}

Tahapan pertama penelitian ini adalah menyusun Peta Persebaran Ruang Terbuka Hijau Publik Sementara. Peta tersebut merupakan hasil dari pengolahan dan interpretasi citra SAS Planet 2017 dengan peta dasar menggunakan perangkat GIS. Kegiatan penelitian dilanjutkan dengan pengecekan lapangan dan survei instansi. Dari sini kemudian akan didapatkan data-data yang diperlukan untuk melengkapi data awal sehingga dapat dilakukan perbaikan peta hasil pengecekan. Peta tersebut juga dilengkapi dengan identifikasi karakteristik masing-masing ruang terbuka hijau publik berdasarkan variabel yang telah ditentukan. Sehingga, didapatkanlah Peta Persebaran Ruang Terbuka Hijau Publik dan karakteristiknya.

\section{HASIL DAN DISKUSI}

\section{A. Proses Pengumpulan Data}

Proses pengumpulan data dilakukan dengan cara survei primer, yaitu observasi lapangan. Pengecekan langsung di lapangan ini ditunjang dengan menggunakan data awal, yaitu Peta Persebaran RTH Publik Sementara untuk mengetahui lokasi ruang terbuka hijau publik yang teridentifikasi dari interpretasi citra. Pengecekan lapangan juga ditunjang dengan menggunakan kuisioner untuk memudahkan pengidentifikasian karakteristik ruang terbuka hijau publik. Kemudian, data observasi ini juga dilengkapi dengan data ruang terbuka hijau publik yang didapatkan dari Dinas Pekerjaan Umum dan Penataan Ruang Kota Pekanbaru. Sehingga, didapatkanlah 48 lokasi ruang terbuka hijau publik dengan karakteristiknya masing-masing.

\section{B. Identifikasi Persebaran Ruang Terbuka Hijau Publik di Kota Pekanbaru}

Kota Pekanbaru terdiri dari 12 kecamatan dimana tersebar ruang terbuka hijau publik. Jumlah ruang terbuka hijau publik yang teridentifikasi adalah 48 lokasi. Rincian masing-masing kecamatan dapat dilihat pada Tabel 1. Peta persebaran ruang terbuka hijau di Kota Pekanbaru dapat dilihat pada Gambar 1.

Tabel 1.

Persebaran RTH Publik di Tiap Kecamatan Kota Pekanbaru

\begin{tabular}{c|c}
\hline \hline Kecamatan & Jumlah RTH Publik \\
\hline Sukajadi & 2 \\
Pekanbaru Kota & 7 \\
Lima Puluh & 1 \\
Sail & 6 \\
Senapelan & 8 \\
Bukit Raya & 2 \\
Tampan & 7 \\
Marpoyan Damai & 4 \\
Payung Sekaki & 4
\end{tabular}

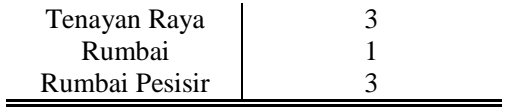

Dari tabel tersebut terlihat bahwa kecamatan yang memiliki ruang terbuka hijau publik paling banyak adalah Kecamatan Senapelan. Sedangkan kecamatan yang memiliki ruang terbuka hijau publik paling sedikit adalah Kecamatan Lima Puluh dan Kecamatan Rumbai. Luas total ruang terbuka hijau publik yang teridentifikasi adalah sebesar 903,02 Ha atau setara dengan 1,43\% dari total luas Kota Pekanbaru. Terdapat perbedaan dengan total luas ruang terbuka hijau publik awal, yaitu sebesar $1,4 \%$. Berdasarkan pengamatan lapangan, hal ini disebabkan oleh karena adanya alihfungsi lahan yang terjadi. Kecamatan yang memiliki proporsi ruang terbuka hijau publik terbesar dari total luas kecamatannya adalah Kecamatan Pekanbaru Kota, yaitu sebesar $10,07 \%$ (22,753 Ha). Sedangkan, kecamatan yang proporsi ruang terbuka hijau publik terkecil adalah Kecamatan Tenayan Raya, yaitu sebesar $0,008 \%(1,481 \mathrm{Ha})$.

Ruang terbuka hijau publik terluas adalah Taman Raya Sultan Syarif Hasyim di Kecamatan Rumbai, dengan luas 806,86 Ha. Sedangkan, ruang terbuka hijau publik terkecil adalah Taman Koridor Labuai di Kecamatan Bukit Raya dengan luas $500 \mathrm{~m}^{2}$.

Dari 48 lokasi ruang terbuka hijau publik yang teridentifikasi, terdiri dari berbagai bentuk, yaitu, taman, lapangan, jalur hijau, hutan kota, dan tempat pemakaman umum.

\section{Taman}

Taman yang teridentifikasi berjumlah 18 lokasi. Taman ini tersebar di sembilan kecamatan dengan luas totalnya adalah sebesar 61,21 Ha. Taman-taman tersebut terletak di Kecamatan Sukajadi sebanyak 1 (Taman Belakang Pustaka Wilayah), Kecamatan Pekanbaru Kota sebanyak 4 (Taman Masjid Raya An-Nur, Taman Kota Dharma Wanita, Taman Ruang Terbuka Hijau Putri Kacang Mayang, Taman Kayu Putih), Kecamatan Sail sebanyak 1 (Taman Cinta Raja), Kecamatan Senapelan sebanyak 4 (Ruang Terbuka Hijau Bawah Jembatan Siak, Ruang Terbuka Hijau Rumah Singgah Tuan Kadi, Ruang Terbuka Hijau Tunjuk Ajar Integritas, Taman Pasar Bawah), Kecamatan Bukit Raya sebanyak 2 (Taman Bandar Seni Raja Ali Haji, Taman Koridor Labuai), Kecamatan Tampan sebanyak 2 (Ruang Terbuka Hijau Stadion Utama Riau, Taman Perumahan Cemara), Kecamatan Marpoyan Damai sebanyak 1 (Taman Wisata Mini Arifin Ahmad), Kecamatan Tenayan Raya sebanyak 1 (Taman Jalur Hijau Sungai Batak), dan Kecamatan Rumbai Pesisir sebanyak 2 (Danau Limbungan, Taman Samping Chevron). Dari segi luas, terdapat 9 taman yang memiliki luas $<5.000 \mathrm{~m}^{2}, 2$ taman yang memiliki luas $5.000-10.000 \mathrm{~m}^{2}, 4$ taman yang memiliki 


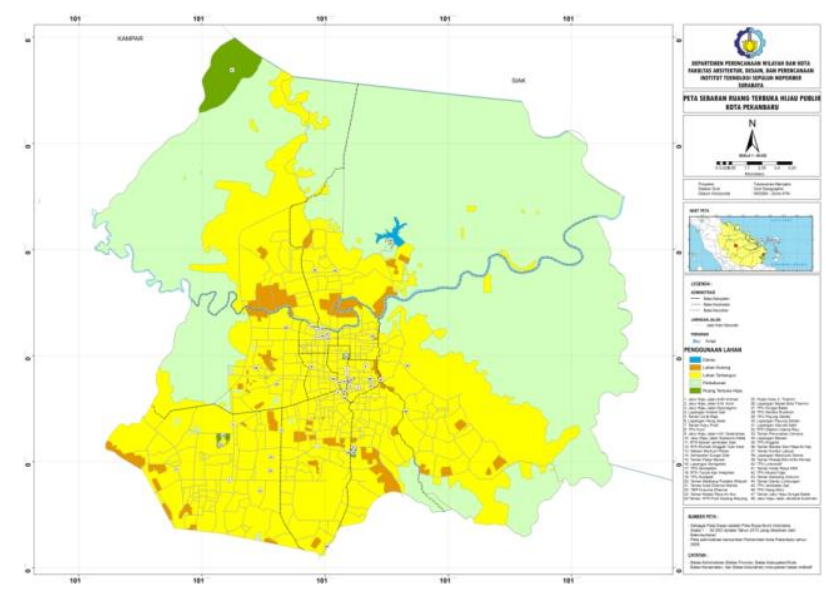

Gambar 1. Sebaran RTH Publik

luas $10.000-15.000 \mathrm{~m}^{2}$, dan $>15.000 \mathrm{~m}^{2}$ sebanyak 3 taman. Dari segi bentuk terdapat 3 taman yang berbentuk persegi, 9 taman yang berbentuk persegi panjang, 4 taman berbentuk segitiga, dan 2 taman yang berbentuk menyebar. Proporsi koefisien dasar hijau taman sebesar 40\%-60\% adalah sebanyak 10 taman, sebesar 70\%-80\% sebanyak 5 taman, dan sebesar 80\%-90\% sebanyak 3 taman. Vegetasi yang teridetifikasi adalah mahoni, matoa, ketapang kecana, angsana, kaliandra, bunga-bungaan, tanjung, dll. Taman yang memiliki variasi vegetasi 1 - 3 adalah sebanyak 6 taman, variasi vegetasi 4 - 6 sebanyak 9 taman, dan > 6 adalah 3 taman. Sarana pendukungnya adalah jogging track, area bermain anak-anak, area duduk, area berjualan, tempat sampah, toilet, kantor pengelola, dll. Ruang terbuka hijau yang memiliki sarana dan prasarana pendukung lengkap berjumlah 9 taman, sedangkan sisanya kurang lengkap. Terdapat perkerasan berupa batu alam. Terdapat 7 taman yang memiliki komponen air, namun, 2 diantaranya tidak berfungsi dengan baik. Aktifitas yang dilakukan masyarakat di taman-taman ini adalah berekreasi dan berolahraga.

Secara keseluruhan, taman yang sudah memadai sebagai ruang terbuka hijau adalah 4 taman, 4 taman yang masih bisa dikembangkan, dan sisanya masih belum memadai.

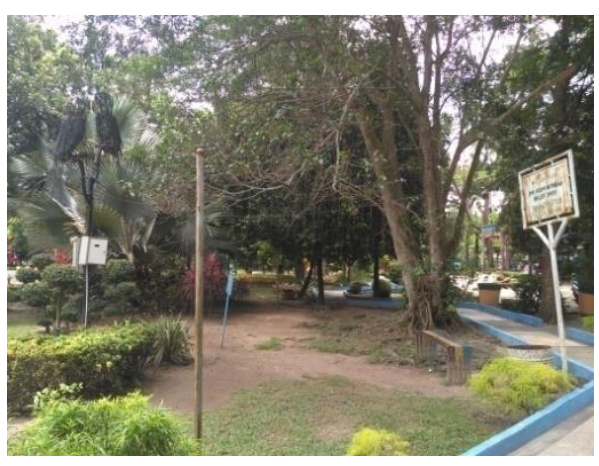

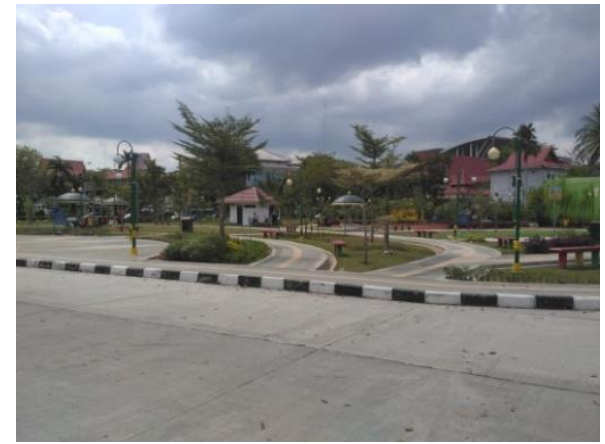

Gambar 2. Taman di Kota Pekanbaru (a) Taman Kota Dharma Wanita, (b) Taman Ruang Terbuka Hijau Putri Kacang Mayang

\section{Tempat Pemakaman Umum}

Tempat pemakaman umum yang teridentifikasi berjumlah 13 lokasi. Tempat pemakaman umum ini tersebar di sembilan kecamatan dengan luas totalnya sebesar 8,34 Ha. Tempat pemakaman umum tersebut terletak di Kecamatan Sukajadi sebanyak 1 (TPU Sukajadi), Kecamatan Pekanbaru Kota sebanyak 1 (Taman Makam Pahlawan Kusuma Dharma), Kecamatan Lima Puluh sebanyak 1 (TPU Lokomotif), Kecamatan Sail sebanyak 1 (TPU Sungai Batak), Kecamatan Senapelan sebanyak 2 (TPU Senapelan, Makam Marhum Pekan), Kecamatan Tampan sebanyak 1 (TPU Anggrek), Kecamatan Marpoyan Damai sebanyak 1 (TPU Kuini), Kecamatan Payung Sekaki sebanyak 2 (TPU Sentiko Muslimin, TPU Payung Sekaki), Kecamatan Tenayan Raya sebanyak 2 (TPU Gang Akhir, TPU Jembatan Sail), dan Kecamatan Rumbai Pesisir sebanyak 1 (TPU Muara Fajar). Dari segi luas, terdapat 2 TPU yang memiliki luas $<5.000 \mathrm{~m}^{2}$, 7 TPU yang memiliki luas $5.000-10.000 \mathrm{~m}^{2}, 2$ TPU yang memiliki luas $10.000-15.000 \mathrm{~m}^{2}$, dan 2 TPU yang memiliki luas $>15.000 \mathrm{~m}^{2}$. Dari segi bentuk terdapat 4 TPU yang berbentuk persegi, 3 TPU yang berbentuk persegi panjang, dan 6 tpu yang berbentuk menyebar. Semua tempat pemakaman umum yang teridentifkasi tersebut memiliki proporsi koefisien dasar hijau sebesar $40 \%$. Vegetasi yang teridentifikasi adalah kamboja, mahoni, petai cina, gajus, dll. Taman yang memiliki variasi vegetasi 1 - 2 adalah sebanyak 7 TPU, variasi vegetasi 3 - 6 sebanyak 5 TPU, dan $>6$ adalah 1 TPU. Semua pemakaman umum memiliki perkerasan pada makamnya.

Secara keseluruhan, tempat pemakaman umum yang sudah memadai sebagai ruang terbuka hijau berjumlah 3, 3 taman yang masih bisa dikembangkan, dan sisanya masih belum memadai.

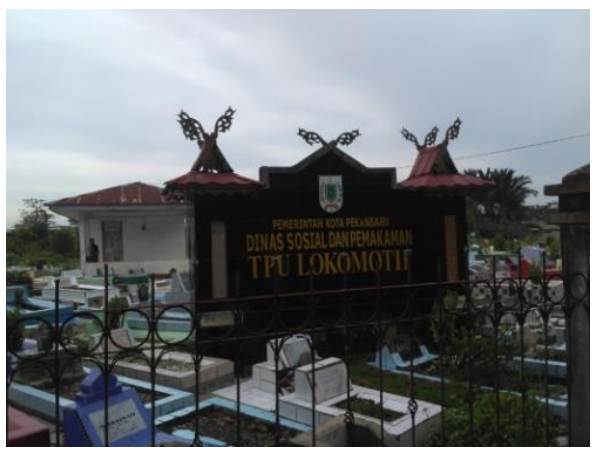




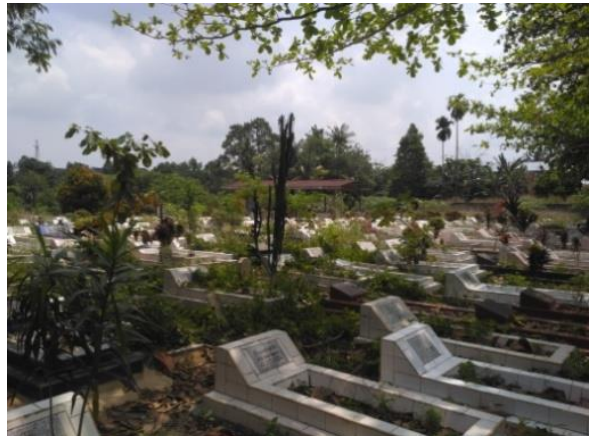

Gambar 3. Tempat Pemakaman Umum di Kota Pekanbaru (a) TPU Lokomotif, (b) TPU Sungai Batak

\section{Lapangan}

Lapangan yang teridentifkasi berjumlah 8 lokasi. Lapangan ini tersebar di lima kecamatan dengan luas totalnya adalah sebesar 5,87 Ha. Lapangan tersebut terletak di Kecamatan Sail sebanyak 3 (Lapangan Kodem Sail, Lapangan Jalan Hang Jebat, Lapangan J1. Thamrin), Kecamatan Senapelan sebanyak 1 (Lapangan Senapelan), Kecamatan Tampan sebanyak 2 (Lapangan Kompleks Marsan, Lapangan Garuda Sakti), Kecamatan Marpoyan Damai sebanyak 1 (Lapangan Marpoyan Damai), dan Kecamatan Payung Sekaki sebanyak 1 (Lapangan Payung Sekaki). Semua bentuknya adalah persegi panjang. Dari segi luas, terdapat 2 lapangan yang memiliki luas $<5.000 \mathrm{~m}^{2}, 4$ lapangan yang memiliki luas $5.000-$ $10.000 \mathrm{~m}^{2}$, dan 2 lapangan yang memiliki luas $10.000-$ $15.000 \mathrm{~m}^{2}$. Semua lapangan yang teridentifikasi tersebut memiliki proporsi koefisien dasar hijau $100 \%$ yaitu rumput dengan pohon dipinggir lapangan. Vegetasi yang teridentifikasi adalah mahoni, kelapa sawit, matoa, tanjung, mangga, kaliandra, ketapang, mahoni, angsana, dll. Terdapat 5 lapangan yang memiliki variasi vegetasi sebanyak 3 dan 3 lapangan yang memiliki variasi vegetasi sebanyak 2 . Semua gawang memiliki gawang, 1 lapangan memiliki area duduk, dan 2 lapangan memiliki area berjualan. Lapangan ini dimanfaatkan oleh masyarakat sebagai area berolahraga.

Secara keseluruhan, lapangan yang sudah memadai sebagai ruang terbuka hijau berjumlah 5 lapangan, sedangkan sisanya masih bisa dikembangkan.

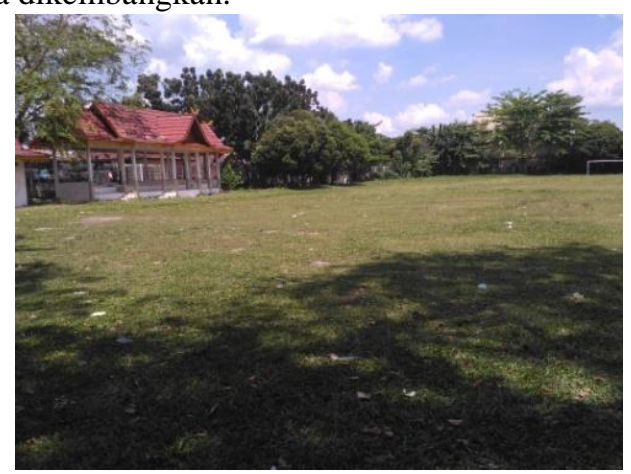

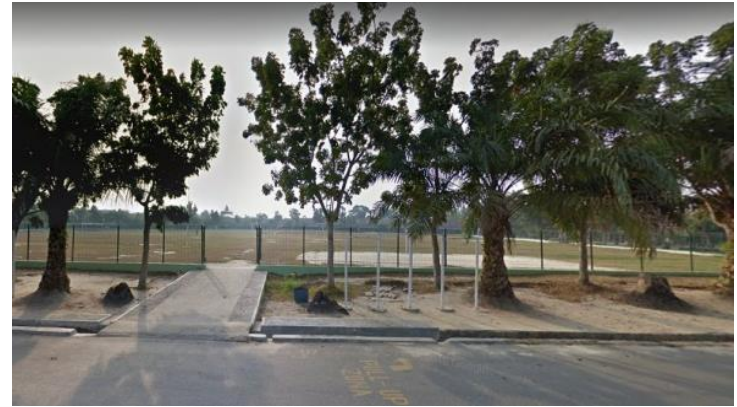

Gambar 4. Lapangan di Kota Pekanbaru (a) Lapangan Senapelan, (b) Lapangan Kodem Sail

\section{Jalur Hijau}

Jalur hijau yang teridentifikasi sebagai ruang terbuka hijau adalah median dan pedestrian jalan utama di Kota Pekanbaru dan sempadan sungai. Terdapat enam jalur hijau dan satu sempadan yang teridentifkasi dengan luas total 14,24 Ha. Jalur hijau tersebut terletak di Kecamatan Pekanbaru Kota sebanyak 2 (jalur hijau Jalan Jenderal Sudirman, jalur hijau Jalan Diponegoro), Kecamatan Tampan sebanyak 2 (jalur hijau Jalan SM. Amin, jalur hijau Jalan HR. Soebrantas), Kecamatan Marpoyan Damai sebanyak 1 (jalur hijau Jalan Arifin Ahmad), dan Kecamatan Payung Sekaki sebanyak 1(jalur hijau Jalan Soekarno-Hatta), dan sempadan Sungai Siak di Kecamatan Senapelan. Dari segi luas, terdapat 3 jalur hijau yang memiliki $5.000-10.000 \mathrm{~m}^{2}, 2$ jalur hijau yang memiliki luas $20.000-30.000 \mathrm{~m}^{2}$, dan 2 jalur hijau yang memiliki luas > $30.000 \mathrm{~m}^{2}$. Semua bentuknya adalah memanjang. Secara umum, karakteristik jalur hijau yang teridentifikasi tersebut adalah, vegetasinya terdiri dari mahoni, bintaro, bunga-bungaan, kamboja, pinang, kamboja india, ketapang, dll. Terdapat 1 jalur hijau yang memiliki variasi vegetasi sebanyak 1, 4 jalur hijau yang variasi vegetasinya sebanyak 4, dan masing-masing 1 jalur hijau dengan variasi vegetasi 5 dan 6 . Jalur hijau yang memiliki jarak tanam $3 \mathrm{~m}$ sebanyak 4 dan jarak tanam 4 m sebanyak 2 .

Secara keseluruhan, terdapat 4 jalur hijau yang sudah memadai sebagai ruang terbuka hijau publik, sedangkan sisanya masih bisa dikembangkan.

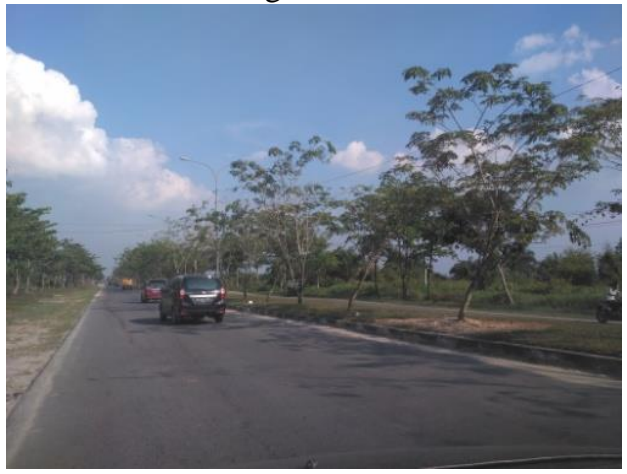




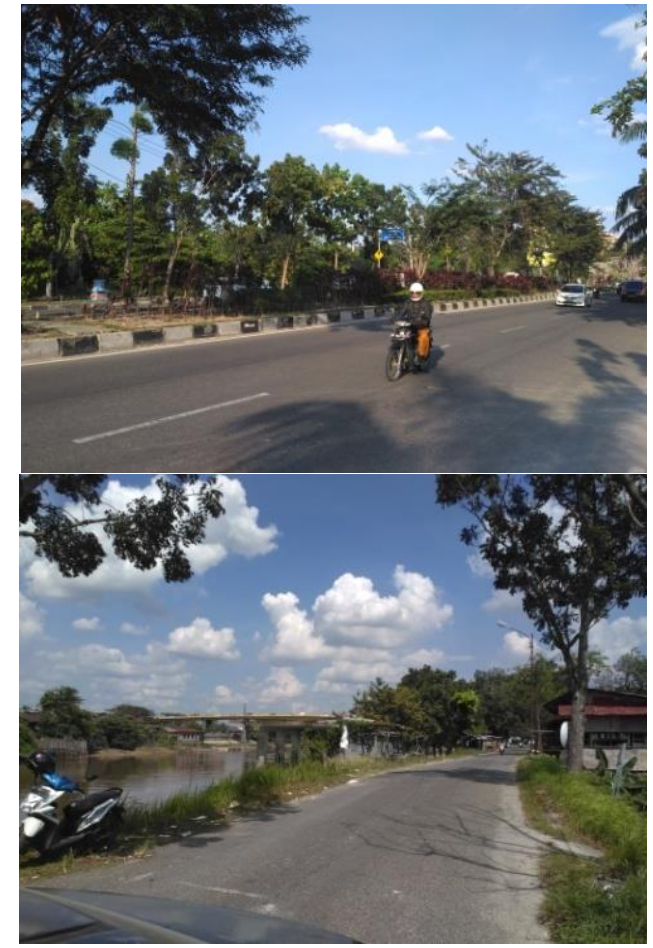

Gambar 5. Jalur Hijau di Kota Pekanbaru (a) Jalur Hijau Jalan SM. Amin, (b) Jalur Hijau Jalan Sudirman, (c) Sempadan Sungai Siak

\section{Hutan Kota}

Hutan kota yang teridentifikasi ada 2, yaitu Hutan Kota JL. Thamrin di Kecamatan Sail yang dikelola oleh Pemerintah Kota Pekanbaru dan Taman Hutan Raya Sultan Syarif Hasyim di Kecamatan Rumbai yang dikelola oleh Pemerintah Provinsi Riau. Hutan Kota J. Thamrin memiliki luas sebesar 5,95 Ha, bentuknya persegi panjang, proporsi koefisien dasar hijaunya adalah sebesar $90 \%$, sarana pendukung yang ada yaitu jogging track, area duduk, mushollah, toilet, dan panggung, vegetasi yang teridentifikasi adalah ketapang, bambu, akasia, gabon, sengon, mahoni, jelutung, dll, terdapat perkerasan berupa semen, dan juga terdapat anak sungai yang mengalir. Taman Hutan Raya Sultan Syarif Hasyim memiliki luas sebesar 806,86 Ha dengan proporsi koefisien dasar hijaunya adalah $90 \%$, bentuknya menyebar, terdapat area bermain anak-anak, gazebo, panggung, jalur sepeda, pusat informasi, gedung serba guna, area kemah, mushollah, dan toilet, vegetasinya adalah gaharu, bintarung, kelat, bengkinang, ludai, meranti, dll, terdapat juga kolam dan danau.

Kedua hutan kota yang teridentifikasi ini sudah memiliki fungsi yang baik sebagai ruang terbuka hijau.

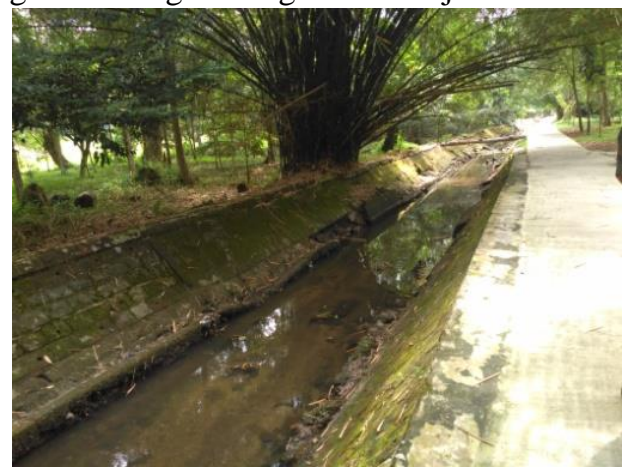

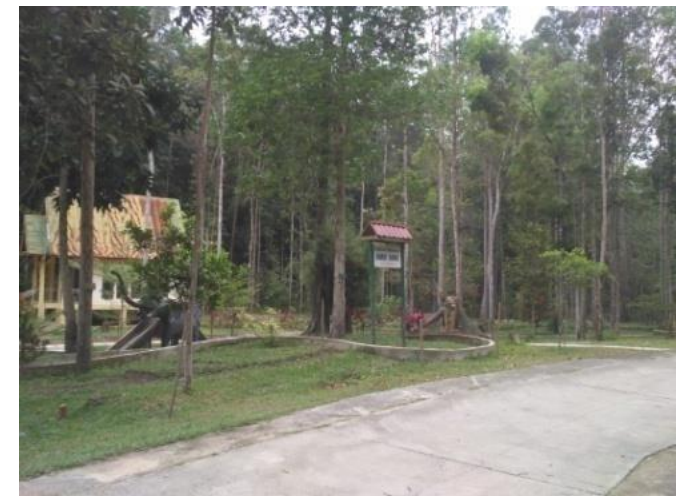

Gambar 6. Hutan Kota di Kota Pekanbaru (a) Hutan Kota Jalan Thamrin, (b) Taman Hutan Raya Sultan Syarif Hasyim

\section{KESIMPULAN/RINGKASAN}

Terdapat 48 ruang terbuka hijau publik di Kota Pekanbaru yang tersebar di seluruh kecamatan. Ruang terbuka hijau publik tersebut terdiri dari taman, tempat pemakaman umum, lapangan, jalur hijau, dan hutan kota. Karakteristik masingmasing ruang terbuka hijau publik berkaitan dengan luas, bentuk, proporsi, vegetasi, pola lansekap, sumber kelembaban, perawatan, dan tingkat peran masyarakat.

\section{DAFTAR PUSTAKA}

[1] L. Setyowati, "Iklim Mikro dan Kebutuhan Ruang Terbuka Hijau di Kota Semarang," in Jurnal Manusia dan Lingkungan Vol.15 No. 3 (2008) 125-140

[2] M. R. Gucci, "Analisis Perbedaan Iklim Mikro terhadap Kenyamanan Pengunjung pada Ruang Terbuka Hijau di Kota Pekanbaru," in Jurnal Lingkungan (2016) 112-120

[3] T. K. Harahap, "Manfaat Ruang Terbuka Hijau sebagai Sarana Interaksi Sosial dan Budaya Masyarakat di Kota Pekanbaru," (2014)

[4] R. Anguluri, "Role of Greenspace in Urban Planning: Outlook Towards Smart Cities," in Urban Forestry \& Urban Greening (2017) 